\title{
TANTANGAN DALAM PENYELENGGARAAN PELAYANAN PUBLIK YANG EFEKTIF PADA PANDEMI COVID 19
}

\author{
Winsherly Tan \\ Fakultas Hukum, Universitas Internasional Batam, Indonesia \\ email: winsherly@uib.ac.id \\ disampaikan 06/10/2020 - di-review 02/11/2020 - diterima 16/11/2021 \\ DOI: $10.25123 /$ vej.v7i2.4300
}

\begin{abstract}
State or government affairs shall be conducted in accordance with the princles of good governance. This is considered a must in normal times and more so when the government have to deal with the COVID-19 pandemic. This general obligation is also in line with the theory proposed by Muchsan about welfare state and government's obligation to provide public services. But reality shows a different picture. The Indonesian government seems to fail in providing good and reliable services in health care, public transport, social assistance, economy, and security. One solution proposed is to appoint a person in charge of managing public complaints. The expectation is that this will empower the public, raise public awareness and increase government capacity to provide for public services.
\end{abstract}

Keywords public service; pandemic; principles of good governance.

\begin{abstract}
Abstrak
Penyelenggaraan Negara Indonesia harus dijalankan sesuai prinsip-prinsip tata pemerintahan yang baik. Prinsip ini berlaku di zaman normal, namun juga ketika Negara menghadapi Pandemi yang diakibatkan COVID-19. Ini sejalan dengan teori yang dikembangkan Muchsan tentang negara kesejahteraan. Persoalan yang ada adalah justru memburuknya kualitas layanan publik yang diberikan di bidang bantuan sosial, keuangan, transportasi, kesehatan dan keamanan. Satu solusi yang dapat direkomendasikan adalah penunjukan penanggung jawab khusus yang memberikan layanan pengaduan publik. Diharapkan dengan itu terjadi peningkatan kesadaran, kapasitas layanan dan pemberdayaan masyarakat.
\end{abstract}

Kata Kunci:

pelayanan Publik; pandemi; asas-asas umum pemerintahan; tata kelola yang baik

\section{Pendahuluan}

Dalam menjalankan sebuah pemerintahan, maka pemerintah tersebut harus dapat memberikan perlindungan dan penjaminan akan hak asasi manusia bersamaan dengan hak warga negara di hadapan hukum dan pemerintahan (equality befor the law). Selain daripada itu, negara sendiri juga harus menghormati hukum dan pemerintahan tanpa terkecuali. ${ }^{1}$

1 Jeffry Alexander Ch. Likadja, "Memaknai "Hukum Negara (Law Through State)" dalam Bingkai "Negara Hukum (Rechtstaat)", Jurnal Hasanuddin Law Review Vol. 1 No. 1, April (2015), hlm., 76. 
Negara Indonesia adalah negara hukum, hal ini sangat tegas diamanatkan dalam Pasal 1 Ayat (3) UUD 1945. Di dalam UUD 1945 ditegaskan bahwa dalam segala lini kehidupan kenegaraan, kemasyarakatan dan termasuk penyelenggaraan pemerintahan harus berdasarkan oleh hukum. Bedasarkan amanat tersebut, maka dengan sangat jelas bahwa segala penyelenggaraan urusan pemerintahan harus mengacu kepada hukum (wetmatigheid van bestuur). ${ }^{2}$ Penyelenggaraan pemerintahan ini diharapkan dapat dilaksanakan dengan baik demi memenuhi hak-hak warga negara. Penyelenggaraan pemerintahan memiliki beberapa tujuan yaitu menciptakan pemerintahan yang bersih, baik serta asasasas umum pemerintahan yang layak. ${ }^{3}$ Oleh sebab itu maka penyelenggaraan pemerintahan harus sesuai dengan asas-asas umum pemerintahan yang baik (AAUPB) sebagaimana yang telah diatur dalam Undang-Undang Nomor 30 Tahun 2014 Tantang Administrasi Pemerintahan.

AAUPB menjadi panduan dan atau acuan bagi negara Indonesia sebagai negara hukum karena AAUPB adalah alat bagi administrasi negara dalam menggapai tujuan dari negara tersebut. AAUPB adalah nilai dan etik yang berkembang di dalam masyarakat itu sendiri yang dimana perlu dipatuhi dan ditepati oleh aparat pemerintahan yaitu baik di tingkat pemerintahan pusat dan daerah. Fungsi dari AAUPB adalah untuk menjadi arahan untuk segala tindakan yang dikerjakan oleh administrasi negara agar hasil pekerjaannya dapat dirasakan secara maksimal dalam mewujudkan pemenuhan hak terhadap warga negara. ${ }^{4}$

Menurut Utrecht, terdapat sebuah perkembangan dari tanggungjawab pemerintag dalam sebuah negara modern yang dimana perkembangan ini menimbulkan adanya asas-asas umum pemerintahan yang baik yang harus difokuskan oleh alat-alat administrasi negara. Utrecht mengemukakan bahwa

2 Tubagus Muhammad Nasarudin, “Asas Dan Norma Hukum Administrasi Negara Dalam Pembuatan Instrumen Pemerintahan”, Jurnal Hukum Novelty, Vol.7 No.2 Agustus 2016, hlm., 140.

3 Yuniar Kurniawaty, "Penggunaan Diskresi Dalam Pembentukan Produk Hukum (The Use Of Discretion In The Formation Of A Legal Product)", Jurnal Legislasi Indonesia, Vol. 13 N0. 01 Maret 2016, hlm., 53.

4 Eny Kusdarini, "Asas-asas Umum Pemerintahan yang Baik pada Produk Hukum Perizinan Investasi Pemerintah Daerah”, Jurnal JH Ius Quia Iustum, Volume 24 Issue 4, Oktober 2017. 
perkembangan tugas dan tanggungjawab pemerintah dalam negara modern inilah yang kemudian memunculkan pemikiran tentang adanya asas-asas umum pemerintahan yang baik yang harus diperhatikan oleh alat administrasi negara. ${ }^{5}$ Kemudian, terhadap negara yang diberikan kewenangan diskresi yang memiliki arti bahwa suatu tindakan yang diambil berdasarkan inisiatif sendiri dengan tujuan penyelesaian persoalan yang mendesak dan hukum tertulis tidak mengaturnya dan serta harus dipertanggungjawabkan secara hukum dan moral. ${ }^{6}$ Pada sebuah negara yang modern seperti negara Indonesia, AAUPB sangat diperlukan dengan tujuan memberikan arahan dan pedoman bagi alat administrasi negara dalam hal menggapai tujuan negara tersebut. ${ }^{7}$

Salah satu bentuk penyelenggaraan pemerintahan dapat dilihat dari pelaksanaan pelayanan publik bagi masyarakat. Salah satu tugas pemerintah adalah menyelenggarakan pelayanan publik yang baik kepada warga negara nya karena tugas tersebut merupakan salah satu tanggung jawab pemerintah yang dilaksanakan oleh instansi pemerintahan baik di tingkat pusat dan daerah serta di lingkungan Badan Usaha Milik Negara. ${ }^{8}$ Dengan adanya peran pemerintah dalam menyelenggarakan pelayanan publik memiliki arti bahwa pemerintah tidak saja melaksanakan peraturan perundang-undangan saja, namun pemerintah berhak menciptakan kaidah hukum konkrit yang dimaksudkan guna mewujudkan tujuan peraturan perundang-undangan. ${ }^{9}$

Pemerintah terus berupaya dalam memberikan pelayanan publik yang maksimal, salah satu caranya adalah mengeluarkan regulasi atau dasar hukum dalam penyelenggaraan pelayanan publik yang baik yaitu pada Undang-Undang

5 Utrecht, Pengantar Hukum Administrasi Negara Indonesia, Cetakan Keempat, Pustaka Tinta Mas, Surabaya, 1994, hlm., 30-31.

6 S.F Marbun, Dimensi-Dimensi Pemikiran Hukum Administrasi Negara, Cetakan Pertama, UII Press, Yogyakarta, 2001, hlm., 202.

7 Eny Kusdarini, Sunarso, dan Setiati Widihastuti, "Pengembangan Asas-Asas Umum Pemerintahan yang Baik Melalui Local Wisdom Keraton Yogyakarta", artikel dalam Jurnal Penelitian Humaniora Vol. 21 No. 1 April 2016, hlm., 23.

8 M. Hamdani Pratama, "Strategi Meningkatkan Kualitas Pelayanan Publik (Studi Deskriptif tentang Strategi UPTD Pengujian Kendaraan Bermotor Tandes Kota Surabaya dalam Meningkatkan Kualitas Pelayanan Pengujian Kendaraan Bermotor)" Junral Kebijakan dan Manajemen Publik, Volume 3, Nomor 3, September -Desember 2015, hlm., 90.

9 Muchsan, Beberapa Catatan Tentang Hukum Administrasi Negara Dan Peradilan Administrasi Negara Di Indonesia. Liberty. Yogyakarta, 1981, hlm., 3. 
Nomor 25 Tahun 2009 Tentang Pelayanan Publik yang memiliki tujuan sebagaimana tertulis dalam pasal 2 yaitu "Undang-undang tentang pelayanan publik dimaksudkan untuk memberikan kepastian hukum dalam hubungan antara masyarakat dan penyelenggara dalarn pelayanan publik".

Pandemi Covid-19 merupakan sebuah wabah virus yang telah menyebar ke seluruh dunia termasuk di negara Indoenesia. Pandemi ini tidak dapat dipandang remeh namun perlu ditangani dengan sangat serius karena pandemi ini berdampak pada setiap aspek kehidupan manusia. Pada era pandemi Covid-19 menimbulkan semakin banyak kebutuhan kehidupan manusia yang perlu di lindungi, dilayani dan diperhatikan. Semakin banyaknya keperluan dan kebutuhan manusia yang perlu dilayani maka perlu adanya pelayanan publik bagi masyarakat yang semakin meningkat.

Sejak pandemi COVID-19, pemerintah pusat dan daerah mengeluarkan kebijakan pada bulan Maret 2020 dalam rangka mencegah penularan virus COVID-19. Kebijakannya adalah pertama, membatasi hubungan fisik/kontak fisik (Phisical distancing) atau biasanya juga disebut sebagai pembatasan hubungan sosial (social distancing). Kedua, adanya anjuran untuk bekerja dari rumah saja (work from home) yang diterapkan oleh Sebagian Aparatur Sipil Negara (ASN). Ketiga, menghimbau masyarakat untuk sebisa mungkin tetap berada di rumah saja (stay at home). Keempat, pemerintah menetapkan adanya Pembatasan Sosial Berskala Besar (PSBB) sebagaimana yang diatur dalam Peraturan Pemerintah Nomor. 21 Tahun 2020 Tentang Pembatasan Sosial Berskala Besar (PSBB). ${ }^{10}$

Kebijakan tersebut dibuat bertujuan untuk memutus rantai penyebaran wabah virus COVID-19. Namun, hal ini menjadi pedang bermata dua yang dimana dapat mencegah penyebaran virus COVID-19, namun disisi lain juga menjadi tantangan dalam penyelenggaraan pemerintah yang baik dalam hal membeirkan pelayanan publik yang tetap harus maksimal kepada warga negara dengan situasi/kebijakan seperti ini.

10 Ombudsman Republik Indonesia, “Dampak Pandemi Covid-19 Bagi Penyelenggaraan Pelayanan Publik", https://ombudsman.go.id/artikel/r/artikel--dampak-pandemi-covid-19bagi-penyelenggaraan-pelayanan-publik, diakses 10 Juni 2020, pukul 13.00 WIB. 
Pengaduan terkait pelayanan publik di era pandemi COVID-19 mengalami tren peningkatan. Sebagai contoh, pertama, melalui survei kepatuhan terhadap pemenuhan standar pelayanan sebagaimana diatur dalam Undang-Undang Nomor 25 Tahun 2009 tentang Pelayanan Publik, khususnya di sejumlah Kabupaten dan Kota yang menjadi sampel, umumnya belum memiliki unit pengaduan, meskipun di tingkat Provinsi telah disediakan, namun untuk memantau 28 Kabupaten dan 1 Kota di Provinsi Papua masih mengalami berbagai kendala. Ketidaktersediaan sarana pengaduan masyarakat dapat mengurangi akuntabilitas pelayanan dimasa pandemi ini, artinya belum maksimal dalam upaya mewujudkan sistem penyelenggaraan pelayanan publik yang layak sesuai dengan asas-asas umum pemerintahan yang baik. ${ }^{11}$ Kedua, laporan pengaduan yang telah masuk ke Layanan Aspirasi dan Pengaduan Online Rakyat (LAPOR!), tercatat sejak Maret hingga 25 Juni 2020, terdapat sebanyak 23.466 laporan. Topik aduan paling banyak mengenai bantuan sosial, ekonomi masyarakat, dan physical distancing. ${ }^{12}$

Metode dalam penelitian ini yaitu yuridis normatif. Jenis data diperoleh dari data sekunder yang terdiri dari: 1) bahan hukum primer yaitu Undang-Undang Dasar 1945, Undang-Undang Nomor 25 Tahun 2009 Tentang Pelayanan Publik, UndangUndang Nomor 30 Tahun 2014 Tentang Administrasi Pemerintahan, Peraturan Pemerintah Republik Indonesia Nomor 96 Tahun 2012 Tentang Pelaksanaan Undang-Undang Nomor 25 Tahun 2009 Tentang Pelayanan Publik, dan Pemerintah (PP) Nomor 24 Tahun 2018 tentang Pelayanan Perizinan Berusaha Terintegrasi secara Elektronik, 2) bahan hukum sekunder yang terdiri dari buku dan jurnal ilmiah yang membahas tentang negara kesejahteraan dan pelayanan publik, serta laporan data terkait pelayanan publik pada website resmi Ombudsman. Analisis data menggunakan landasan yuridis dan landasan teoritis yaitu Teori Kesejahteraan Negara oleh Muchsan dan Teori Efektivitas Hukum Oleh

11 Ombudsman Republik Indonesia, "Mengawasi Pelayanan Publik Di Masa Pandemi Covid-19", ttps://ombudsman.go.id/artikel/r/artikel--mengawasi-pelayanan-publik-di-masa-pandemicovid-19, diakses 24 September 2020, pukul 14.00 WIB.

12 Mahendra Bungalan, Suara Merdeka, "Masyarakat Keluhkan Pelayanan Publik di Masa Pandemi, Bisa LAPOR!", https://www.suaramerdeka.com/news/nasional/233324masyarakat-keluhkan-pelayanan-publik-di-masa-pandemi-bisa-lapor, diakses 25 September 2020, pukul 14.00 WIB. 
Soerjono Soekanto, dianalisa dengan metode kualitatif, artinya menganalisis keseluruhan dan diimplementasikan dengan menyusun data yang telah dikumpulkan secara sistematis dan menghasilkan kesimpulan.

Tujuan dalam penelitian ini yaitu: pertama, untuk mengetahui dan mengkaji lebih dalam terkait pelaksanaan pelayanan publik di era pandemi COVID-19 yang seharusnya pelayanan publik tidak boleh mengalami penuranan standar walaupun di era pandemi COVID-19 seperti saat ini. Kedua, untuk mengetahui tentang efektivitas pelayanan publik pada era pandemi COVID-19.

\section{Pembahasan}

\section{Pelaksanaan Pelayanan Publik di Era Pandemic COVID-19}

Negara Indonesia termasuk negara yang menyatakan dirinya sebagai negara kesejahteraan (Welfare State). Hal ini tercermin dalam Undang-Undang Dasar 1945 yang secara tegas menyatakan bahwa tujuan dari negara adalah untuk mensejahterakan kehidupan bangsa. Sebagai sebuah negara kesejahteraan, maka pemerintahan sebuah negara tersebut harus dapat menjalankan fungsi dan tugas dalam memenuhi kebutuhan dasar hidup warganya (basic needs) seperti kebutuhan sandang, pangan dan papan serta pelayanan sosial lainnya yang dimana kebutuhan ini harus terpenuhi untuk seluruh lapisan warga negara tanpa terkecuali. ${ }^{13}$

Membahas tentang pelayanan publik hal ini menyangkut berbagai aspek kehidupan manusia yang sangat luas. Dalam kehiduapan bermasyarakat, pemerintah meruapakan subjek yang paling bertanggung jawab dalam menjalankan fungsinya dalam memenuhi kebutuhan masyarakat melalui pelayanan publik yang diberikan seperti pelayanan dalam bidang pendidikan, kesehatan, dan lainnya yang menjadi dasar pokok kebutuhan warga negara. ${ }^{14}$

\footnotetext{
13 Nur Rohim Yunus, "Aktualisasi Welfare State Terhadap Kehidupan Bernegara Dalam Dimensi Keislaman dan Keindonesiaan", Jurnal Ilmu Syariah,FAI Universitas Ibn Khaldun (UIKA) BOGORVol. 3No. 2(2015), hlm., 253.

14 Ali Abdul Wakhid, "Reformasi Pelayanan Publik di Indonesia", Jurnal TAPIs Nomor 14 Volume 01 Januari-Juni 2017, hlm., 54.
} 
Negara Indonesia termasuk negara yang memiliki komitmen dalam menyelenggarakan pelayanan publik yang optimal bagi masyarakat. Salah satu buktinya adalah dibentuknya dibentuknya Undang-Undang Nomor 25 Tahun 2009 Tentang Pelayanan Publik. Tujuan dibentuknya undang-undang tersebut adalah:

a. terwujudnya batasan dan hubungan yang jelas tentang hak, tanggung jawab, kewajiban, dan kewenangan seluruh pihak yang terkait dengan penyelenggaraan pelayanan publik;

b. terwujudnya sistem penyelenggaraan pelayanan publik yang layak sesuai dengan asas-asas umum pemerintahan dan korporasi yang baik;

c. terpenuhinya penyelenggaraan pelayanan publik sesuai dengan peraturan perundang-undangan; dan

d. terwujudnya perlindungan dan kepastian hukum bagi masyarakat dalam penyelenggaraan pelayanan publik.

Penyelenggaraan pelayanan publik ini juga harus berdasarkan pada asasasas pelayanan publik sebagaimana yang diatur dalam pasal 4 Undang-Undang Nomor 25 Tahun 2009 Tentang Pelayanan Publik yaitu:

"asas kepentingan umum, kepastian hukum, kesamaan hak, keseimbangan hak dan kewajiban, keprofesionalan, partisipatif, persamaan perlakuan/tidak diskriminatif, keterbukaan, akuntabilitas, fasilitas dan perlakuan khusus bagi kelompok rentan, ketepatan waktu, kecepatan, kemudahan dan keterjangkauan".

Pada era pandemi COVID-19 ini, muncul semakin banyak kebutuhan masyarakat yang perlu dipenuhi dan dilayani. Pada era pandemi COVID-19 ini, mengalami tren pengaduan terkait pelayanan publik yang terjadi. Menurut keterangan dari Ketua Ombudsman Republik Indonesia menyatakan bahwa15 berdasarkan data yang masuk ke posko pengaduan daring COVID-19, Ombudsman Republik Indonesia menerima 387 laporan pengaduan masyarakat terkait kebijakan pemerintah yang menyangkut layanan publik di tengah pandemi COVID-19.

15 Kompas, “Ombudsman Kantongi 387 Pengaduan Terkait Penurunan Kualitas Layanan Publik di Tengah Pandemi",

https://nasional.kompas.com/read/2020/05/14/10035381/ombudsman-kantongi-387pengaduan-terkait-penurunan-kualitas-layanan-publik?page=all, diakses 25 September 2020 , pukul 12.00 WIB. 
Berdasarkan data dari Ombudsman Republik Indonesia, laporan pengaduan yang masuk tersebut mayoritas adalah aduan/laporan mengenai bantuan sosial (bansos) yang diberikan selama pandemi COVID-19 yang dimana jumlah aduan/laporan sebanyak 72 persen atau 278 pengaduan, terkait persoalan keuangan sebanyak 23 persen atau 89 pengaduan, terakit persoalan transportasi dan pelayanan kesehatan sebanyak 2 persen atau 8 pengaduan, kemudian terkait keamanan sebanyak 1 persen atau 4 pengaduan. ${ }^{16}$

Sementara itu, berdasarkan lokasi pengaduan, dapat memperhatikan tabel dibawah ini:

Tabel 1: Lokasi Pengaduan Tahun 2020

\begin{tabular}{llll}
\hline No & \multicolumn{1}{c}{ Lokasi } & Jumlah Aduan & Persentase \\
\hline 1 & DKI Jakarta & 47 aduan & $12 \%$ \\
\hline 2 & Sumatera Barat & 44 aduan & $11,37 \%$ \\
\hline 3 & Banten & 34 aduan & $8,79 \%$ \\
\hline 4 & Sulawesi Sleatan & 26 aduan & $6,72 \%$ \\
\hline 5 & Jawa Barat & 24 aduan & $6,20 \%$ \\
\hline 6 & Daerah Istimewa Yogyakarta & 23 aduan & $5,94 \%$ \\
\hline $\mathbf{7}$ & Jawa Timur & 22 aduan & $5,68 \%$ \\
\hline $\mathbf{8}$ & Jawa Tengah & 21 aduan & $5,43 \%$ \\
\hline
\end{tabular}

Sumber: Ombudsman Republik Indonesia

Terdapat beberapa jenis aduan terkait pelayanan publik di era pandemi COVID-19, yaitu sebagai berikut:

\section{Tabel 2: Jenis Aduan Pelayanan Publik di Era Pandemi COVID-19 Tahun 2020}

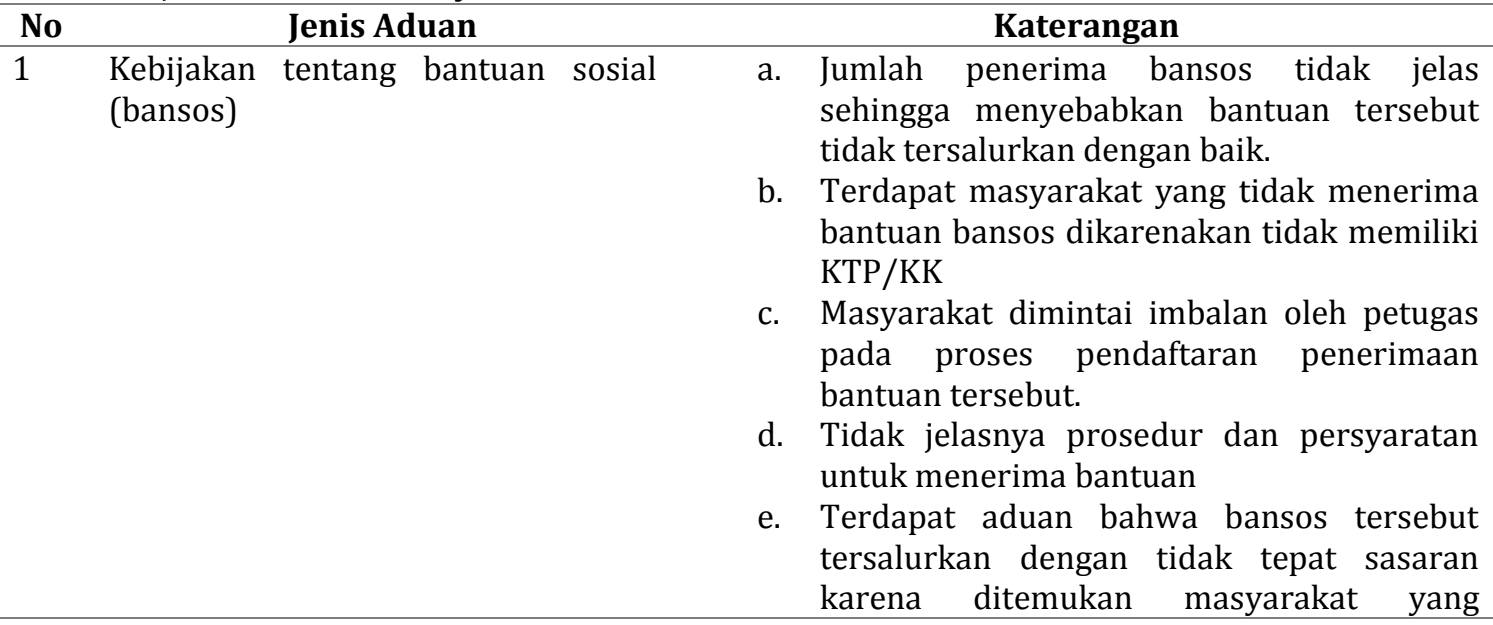

16 Ombudsman, "Selama Pandemi Covid-19, Ombudsman Terima 1.346 Pengaduan Soal Bansos", https://ombudsman.go.id/news/r/selama-pandemi-covid-19-ombudsman-terima-1346pengaduan-soal-bansos, diakses 19 April 2021, pukul 12.00 WIB. 


\begin{tabular}{|c|c|c|c|}
\hline & & & $\begin{array}{l}\text { terdampak wabah Covid-19 namun tidak } \\
\text { terdaftar sebagai penerima bantuan. }\end{array}$ \\
\hline 2 & Aduan terkait keuangan & a. & $\begin{array}{l}\text { Informasi terkait kebijakan relaksasi kredit } \\
\text { yang diperuntukan masyarakat belum jelas. } \\
\text { Prosedur dan mekanisme permohonan } \\
\text { restrukturisasi kredit bagi sejumlah } \\
\text { masyarakat yang telah memenuhi kriteria } \\
\text { belum dilaksanakan dengan jelas. }\end{array}$ \\
\hline 3 & Aduan terkait pelayanan kesehatan & a. & $\begin{array}{l}\text { Kurangnya informasi tentang perbedaan } \\
\text { klasifikasi pasien Covid- } 19 \text {. } \\
\text { Kurangnya informasi tentang tempat isolasi. }\end{array}$ \\
\hline 4 & Aduan terkait transportasi & a. & $\begin{array}{l}\text { Penghentian angkutan umum di daerah } \\
\text { yang belum ditetapkan sebagai PSBB hingga } \\
\text { tidak adanya sarana transportasi ke daerah } \\
\text { asal bagi WNI yang baru dipulangkan dari } \\
\text { luar negeri. }\end{array}$ \\
\hline 5 & Aduan terkait keamanan & a. & $\begin{array}{l}\text { Tidak maksimalnya penertiban krumunan } \\
\text { orang yang berkumpul pada zona PSBB. } \\
\text { Ketidakjelasan proses penahanan terhadap } \\
\text { tersangka yang berstatus positif Covid-19. }\end{array}$ \\
\hline
\end{tabular}
Sumber: Posko Pengaduan Daring Ombudsman Republik Indonesia ${ }^{17}$

Berdasarkan kondisi pelayanan publik yang terjadi di era pandemi COVID19 ini, dapat diketahui bahwa pelayanan publik menjadi salah satu hal yang perlu diperhatikan. Pada era pandemi seperti saat ini semakin banyak kebutuhan dasar masyarakat yang harus dipenuhi sehingga pelayanan publik yang diberikan juga harus maksimal dalam menjawab kebutuhan tersebut. Jika kita ukur dengan asas penyelenggaraan pelayanan publik sebagaimana yang diatur dalam Pasal 4 Undang-Undang Nomor 25 Tahun 2009, yaitu sebagai berikut:

a. Asas kepentingan umum menurut Undang-Undang Nomor 30 Tahun 2014 memiliki arti yaitu "pemberian pelayanan tidak boleh mengutamakan kepentingan pribadi dan/'atau golongan". Asas ini memberikan arti bahwa pelayanan publik harus didapatkan oleh semua orang tanpa terkecuali. Tujuan dari asas kepentingan umum adalah untuk mewujudkan ketertiban dan kenyamanan untuk seluruh masyarakat dan berharap masyarakat akan menjadi lebih baik. Jika dilihat dari kasus yang terjadi (Tabel 2), masih terdapat pelayanan publik pada era pandemi ini yang belum mencerminkan

17 Kompas, “Ombudsman Kantongi 387 Pengaduan Terkait Penurunan Kualitas Layanan Publik di Tengah Pandemi" (https://nasional.kompas.com/read/2020/05/14/10035381/ombudsman-kantongi-387pengaduan-terkait-penurunan-kualitas-layanan-publik?page=all), diakses 19 April 2021, pukul 13.00 WIB. 
adanya asas kepentingan umum yaitu adanya penyaluran bantuan yang tidak merata ke seluruh masyarakat yang seharusnya menerima bantuan tersebut. Akibat dari hal tersebut, maka tidak semua masyarakat yang keadaannya menjadi lebih baik karena tidak semua masyarakat yang harusnya menerima bantuan dapat menerima bantuan sebagaimana mestinya

b. Asas kepastian hukum menurut Undang-Undang Nomor 30 Tahun 2014 memiliki arti yaitu "adanya jaminan terwujudnya hak dan kewajiban dalam penyelenggaraan pelayanan". Tujuan dari asas ini adalah mewujudkan hak and kewajiban pelayanan sebagaimana yang telah diatur dalam undang-undang. Dalam penyelenggaraan pelayanan publik, Indonesia telah memiliki peraturan yang menjadi dasar dalam penyelenggaraan pelayanan publik yaitu UndangUndang Nomor 25 Tahun 2009 Tentang Pelayanan Publik. Secara dasar hukum, penyelenggaraan pelayanan publik telah memiliki kepastian hukum dalam pelaksanaan hak dan kewajiban penyelenggaraan pelayanan publik. Namun dalam pelaksanaannya terutama pada era pandemi, tidaklah begitu mudah dalam penyelenggaraan hak dan kewajiban tersebut. Berdasarkan kasus pelayanan publik yang saat ini (Tabel 2) terjadi maka dapat disimpulkan bahwa belum secara maksimal terwujudnya hak dan kewajiban dalam penyelenggaraan pelayanan publik terkait bantuan sosial, keuangan, kesehatan, transportasi dan keamanan karena masih terdapat banyak hak warga negara yang belum terpenuhi dari kelima kebutuhan masyarakat tersebut seperti penyaluran bantuan sosial belum menyeluruh ke smeua daerah, bantuan keuangan yang belum jelas prosedurnya dan belum jelasnya informasi tentang alur pelayanan kesehatan bagi masyarakat.

c. Asas keseimbangan hak dan kewajiban menurut Undang-Undang Nomor 30 Tahun 2014 memiliki arti yaitu "pemenuhan hak harus sebanding dengan kewajiban yang harus dilaksanakan, baik oleh pemberi maupun penerima pelayanan". Asas ini memiliki makna bahwa antara hak dan kewajiban antara pemberi dan penerima pelayanan tersebut harus seimbang, tidak hanya berbicara tentang pemenuhan hak untuk penerima pelayanan tapi harus seimbang antara hak dan kewajiban antara pemberi dan penerima pelayanan. 
Jika dilihat dari kasus penyelenggaraan pelayanan publik yang terjadi di era pandemi (Tabel 2) terdapat 2 (dua) kejadian yang belum mencerminkan asas keseimbangan hak dan kewajiban ini yaitu pertama, terkait penyaluran bantuan sosial yang belum merata. Masih terdapat masyarakat yang tidak mendapatkan bantuan tersebut dikarenakan tidak memiliki administrasi yang lengkap seperti tidak memiliki KTP dan KK. Dalam hal ini, penerima pelayanan publik tidak memenuhi kewajibannya dalam melengkapi administrasi sehingga hak nya sebagai penerima pelayanan tidak dapat dipenuhi. Kedua, terkait aduan tentang keuangan yang masuk pada data Posko Pengaduan Ombudsman (Tabel 2), dilaporkan bahwa belum adanya layanan secara jelas terkait prosedur dan mekanisme permohonan restrukturisasi kredit bagi sejumlah masyarakat yang telah memenuhi kriteria. Dalam hal ini, terlihat bahwa masyarakat telah memenuhi kewajibannya dalam pemenuhan kriteria sebagai penerima bantuan, namun belum ada layanan yang jelas dalam memperoleh hak nya sebagaimana mestinya.

d. Asas keprofesionalan menurut Undang-Undang Nomor 30 Tahun 2014 memiliki arti yaitu "pelaksana pelayanan harus memiliki kompetensi yang sesuai dengan bidang tugas". Berdasarkan kasus pelayanan publik yang terjadi, belum terlihat indikasi bahwa pelayanan publik yang diselenggarakan ditangani oleh sumber daya manusia yang tidak sesuai kompetensi.

e. Asas partisipatif menurut Undang-Undang Nomor 30 Tahun 2014 memiliki arti yaitu "peningkatan peran serta masyarakat dalam penyelenggaraan pelayanan dengan memperhatikan aspirasi, kebutuhan, dan harapan masyarakat". Berdasarkan kasus pelayanan publik yang terjadi, terlihat bahwa kurangnya partisipasai masyarakat dalam mensukseskan pelayanan publik yang sudah ditentukan oleh pemerintah, contohnya di bidang keamanan, masyarakat melaporkan kurang ditertibkannya kerumunan orang yang masih dalam zona penerapan PSBB. Penerapan PSBB ini dapat dilaksanakan dengan baik jika seluruh masyarakat berpartisipasi dengan disiplin dalam menerapkan PSBB. 
f. Asas persamaan perlakuan/tidak diskriminatif menurut Undang-Undang Nomor 30 Tahun 2014 memiliki arti yaitu "setiap warga negara berhak memperoleh pelayanan yang adil”. Berdasarkan kasus pelayanan publik yang terjadi, dapat diketahui bahwa adanya pelayanan publik yang kurang adil seperti pembagian bantuan sosial yang belum merata ke setiap daerah.

g. Asas keterbukaan menurut Undang-Undang Nomor 30 Tahun 2014 memiliki arti yaitu "setiap penerima pelayanan dapat dengan mudah mengakses dan memperoleh informasi mengenai pelayanan yang diinginkan". Berdasarkan kasus pelayanan publik yang terjadi, permasalahan yang paling disoroti dari pelayanan publik adalah mengenai ketebukaan informasi yang jelas seperti dalam bidang keunagan, belum tersedianya informasi secara jelas mengenai kebijakan relaksasi kredit kepada masyarakat. Kemudian belum adanya layanan secara jelas terkait prosedur dan mekanisme permohonan restrukturisasi kredit bagi sejumlah masyarakat yang telah memenuhi kriteria. Kemudian terkait layanan Kesehatan juga terdapat aduan bahwa kurangnya informasi tentang alur pelayanan kesehatan bagi masyarakat dengan gejala mirip Covid-19, termasuk informasi tentang tempat isolasi.

h. Asas Akuntabilitas menurut Undang-Undang Nomor 30 Tahun 2014 memiliki arti yaitu "proses penyelenggaraan pelayanan harus dapat dipertanggungjawabkan". Berdasarkan kasus pelayanan publik yang terjadi dalam berbagai bidang pelayanan yang dilaporkan oleh masyarakat, belum sepenuhnya memenuhi asas akuntabilitas.

i. Asas fasilitas dan Perlakuan khusus bagi kelompok rentan menurut UndangUndang Nomor 30 Tahun 2014 memiliki arti yaitu "pemberian kemudahan terhadap kelompok rentan sehingga tercipta keadilan dalam pelayanan". Berdasarkan kasus pelayanan publik yang terjadi, belum ditemukannya laporan atau aduan yang berkaitan dengan pelayanan publik yang diberikan oleh kelompok yang rentan.

j. Asas ketepatan waktu menurut Undang-Undang Nomor 30 Tahun 2014 memiliki arti yaitu "penyelesaian setiap jenis pelayanan dilakukan tepat waktu sesuai dengan standar pelayanan". Berdasarkan kasus pelayanan publik yang 
terjadi, masalah yang utama yang disoroti adalah terkait ketersediaan informasi yang jelas. Jika informasi yang diberikan saja tidak jelas, maka waktu pemberian pelayanan publik tersebut juga tidak akan tepat pada waktunya.

k. Asas kecepatan, Kemudahan dan Keterjangkauan menurut Undang-Undang Nomor 30 Tahun 2014 memiliki arti yaitu "setiap jenis pelayanan dilakukan secara cepat, mudah, dan terjangkau". Berdasarkan kasus pelayanan publik yang terjadi, tidak dapat dikatakan cepat dan mudah karena belum ada prosedur pelayanan publik yang jelas dan keterbukaan informasi terkait pelayanan publik yang memadai.

Berdasarkan hasil penelitian tersebut, maka dapat diketahui bahwa pelaksanaan pelayanan publik yang terjadi di era pandemi COVID-19 memang perlu diperhatikan dan dilakukan perbaikan karena jika diukur dengan asas-asas pelayanan publik sebagaimana yang ditentukan dalam pasal 4 Undang-Undang Nomor 25 Tahun 2009 Tentang Pelayanan Publik, pelaksanaan pelayanan publik yang ada belum memenuhi dan mencerminkan kesemua asas-asas pelayanan publik tersebut.

\section{Pelayanan Publik yang Layak Berdasarkan Asas Umum Pemerintahan yang Baik Pada Era Pandemi COVID-19}

Hukum Administrasi (HAN) merupakan instrumen hukum paling klasik untuk terselenggaranya pemerintahan yang baik. Penyelenggaraan pemerintahan lebih nyata dalam HAN, karena di sini akan terlihat konkrit hubungan antara pemerintah dengan masyarakat, kualitas dari hubungan pemerintah dengan masyarakat inilah setidaknya dapat dijadikan ukuran apakah penyelenggaraan pemerintahan sudah baik atau belum. ${ }^{18}$ Dalam Hukum Administrasi Negara inilah keberadaan praktek administrasi/hukum tidak tertulis (lex ne scripta) dikenal dengan sebutan AAUPB (algemene beginselen van behoorlijk bestuuratau the general principles of good governance). AAUPB sebagai sumber Hukum Administrasi Negara yang tidak tertulis dapat ditelusuri dalam bentuk

18 Arfan Faiz Muhlizi, "Reformulasi Diskresi Dalam Penataan Hukum Administrasi", Jurnal Rechts Vinding, Volume 1 Nomor 1 Januari-April 2012, hlm., 94. 
yuriprudensi dan doktrin. ${ }^{19}$ Menurut Philipus M. Hadjon, AAUPB merupakan sebuah norma-norma hukum tidak tertulis yang dimana asas-asas tersebut wajib ditaati oleh pemerintah. Hal ini memiliki arti bahwa AAUPB adalah asas-asas hukum tidak tertulis. ${ }^{20}$

Menurut Undang-Undang Nomor 30 Tahun 2014 Tentang Administrasi Pemerintahan, Asas-asas Umum Pemerintahan yang Baik yang selanjutnya disingkat AUPB adalah prinsip yang digunakan sebagai acuan penggunaan Wewenang bagi Pejabat Pemerintahan dalam mengeluarkan Keputusan dan/atau Tindakan dalam penyelenggaraan pemerintahan. Kemudian pada pasal 10 (1) AUPB yang dimaksud dalam Undang-Undang ini meliputi asas kepastian hukum, kemanfaatan, ketidakberpihakan, kecermatan, tidak menyalahgunakan kewenangan, keterbukaan, kepentingan umum dan pelayanan yang baik. Kemudian yang dimaksud dengan "asas pelayanan yang baik" adalah asas yang memberikan pelayanan yang tepat waktu, prosedur dan biaya yang jelas, sesuai dengan standar pelayanan, dan ketentuan peraturan perundang-undangan. ${ }^{21}$

Standar pelayanan yang dimaksud pada Pasal 10 Undang-Undang Nomor 30 Tahun 2014 Tentang Administrasi Pemerintahan tersebut dijelaskan lebih rincih dalam Pasal 13 Peraturan Pemerintah Republik Indonesia Nomor 96 Tahun 2012 Tentang Pelaksanaan Undang-Undang Nomor 25 Tahun 2009 Tentang Pelayanan Publik yaitu sistem pelayanan terpadu dilaksanakan dengan beberapa prinsip yaitu keterpaduan, ekonomis, koordinasi, pendelegasian, akuntabilitas, aksesibilitas. Berikut adalah hasil analisis pelayanan public yang terjadi di era pandemi Covid-19 dengan standar pelayanan publik yang sudah ditentukan oleh pemerintah, yaitu sebagai berikut:

a. Keterpaduan memiliki makna sebagaimana ditulis dalam Peraturan Pemerintah Republik Indonesia Nomor 96 Tahun 2012, yaitu “pengintegrasian proses penyelesaian berbagai jenis pelayanan dalam satu sistem". Makna

19 Sanggup Leonard Agustian, "Asas-Asas Umum Pemerintahan Yang Baik Sebagai Batu Uji Bagi Hakim Dalam Memutus Sengketa Peradilan Administrasi Negara", Jurnal Hukum Magnum Opus, Volume 2 Nomor 2 Agustus 2019, hlm., 149.

20 Solechan, "Asas-Asas Umum Pemerintahan yang Baik dalam Pelayanan Publik", Jurnal Adminitrative Law \& Governance, Volume 2 Nomor 3, Agustus 2019, hlm., 541.

21 Pasal 10, Undang-Undang Nomor 30 Tahun 2014 Tentang Administrasi Pemerintahan. 
keterpaduan adalah implementasi dari pelayanan publik dapat dilihat dari dasar hukum, persyaratan dan sistem mekanisme dan prosedur dalam penyelenggaraan pelayanan publik. Jika dilihat dari kasus penyelenggaraan pelayanan publik yang terjadi pada era pandemi (Tabel 2), Indonesia telah memiliki dasar hukum dalam mengatur pelayanan publik, bahkan terdapat standar dalam pelayanan tersebut sebagaimana yang telah diatur dalam Peraturan Pemerintah Nomor 96 Tahun 2012. Walaupun telah memiliki dasar hukum yang memadai dalam penyelenggaraan pelayanan publik, namun masih ditemukan adanya prosedur penyelenggaraan pelayanan publik yang belum memadai yaitu terkait dengan aduan keuangan terdapat aduan bahwa adanya prosedur dan mekanisme permohonan restrukturisasi kredit yang belum jelas.

b. Ekonomis memiliki makna sebagaimana ditulis dalam Peraturan Pemerintah Republik Indonesia Nomor 96 Tahun 2012, yaitu "tidak menimbulkan ekonomi biaya tinggi bagi Masyarakat". Ekonomis yang dimaksud di sini adalah menganai biaya pelayanan yang di keluarkan harus memperhatikan keterjangkauan masyarakat dan disesuaikan biaya yang dibayar dengan biaya yang telah diatur serta rincian biayanya harus jelas. ${ }^{22}$ Jika dilihat dari data aduan (Tabel 2), terdapat hal yang tidak mencerminkan standar ekonomis ini yaitu ditemukan adanya aduan masyarakat bahwa masyarakat diminta imbalan dari aparatur pemerintah yang menyelenggarakan pelayanan publik.

c. Koordinasi memiliki makna sebagaimana ditulis dalam Peraturan Pemerintah Republik Indonesia Nomor 96 Tahun 2012, yaitu “jenis-jenis pelayanan yang dipadukan tidak berjalan sendiri-sendiri, tetapi harus berjalan dalam 1 (satu) tim kerja yang benar-benar terpadu dan terkoordinasi dengan misi yang sama untuk memberikan pelayanan yang terbaik bagi masyarakat". Koordinasi ini sangat penting dan hal ini berkaitan dengan waktu dalam penyelesaian pelayanan publik yang bertujuan untuk menghasilkan pelayanan yang prima jika dapat menyelenggarakan pelayanan publik dalam jangka waktu yang

22 Veronika Erlin, "Implementasi Prinsip Pelayanan Publik Di Kelurahan Tasikmadu Berdasarkan Peraturan Pemerintah No 96 Tahun 2012 Tentang Pelayanan Publik", Jurnal Ilmu Sosial dan Ilmu Politik, Volume 5, Nomor 1, 2016, hlm., 54. 
singkat dan cepat. Berdasarkan data pengaduan pelayanan publik yang masuk pada posko Ombudsman Republik Indonesia (Tabel 2), maka tidak terlihat bahwa adanya koordinasi yang baik. Sebagai contoh, adanya aduan dalam bidang Kesehatan yaitu ditemukan adanya keterlambatan penyampaian hasil tes Covid-19 kepada pasien hingga kurangnya jumlah tenaga medis untuk menangani pasien Covid-19. Hal ini timbul karena faktor minimnya koordinasi yang terjadi sehingga menyebabkan pelayanan yang tidak prima.

l. Akuntabilitas memiliki makna sebagaimana ditulis dalam Peraturan Pemerintah Republik Indonesia Nomor 96 Tahun 2012, yaitu "pelayanan yang diberikan melalui sistem pelayanan terpadu harus benar-benar dapat dipertanggungjawabkan sesuai peraturan perundang-undangan”. Berdasarkan kasus pelayanan publik yang terjadi pada era pandemi (Tabel 2) dari berbagai aduan yang masuk ke posko Ombudsman dapat diketahui belum mencerminkan asas akuntabilitas karena terdapat berabagai kelemahan yaitu pertama, masih belum semua orang yang seharusnya menerima bantuan sosial menerima nya dengan baik dikarenakan adanya ketidaklengkapan administrasi yang belum dipenuhi oeh penerima bantuan. Kedua, terkait aduan keuangan yang dimana masih terdapat prosedur yang kurang jelas dalam permohonan restrukturisasi kredit. Ketiga, kurangnya informasi tentang tempat isolasi padahal masyarakat berhak untuk mengetahui hal ini. Keempat, kurang tertibnya penerapan PSBB.

m. Aksesibilitas memiliki makna sebagaimana ditulis dalam Peraturan Pemerintah Republik Indonesia Nomor 96 Tahun 2012, yaitu "Masyarakat memiliki akses yang mudah untuk mendapatkan pelayanan". Makna asesibilitas adalah ketersediaan pelayanan publik yang mudah dicapai oleh seluruh kalangan. Jika dilihat dari kasus pelayanan public yang terjadi di era pandemi (Tabel 2), permasalahan yang paling disoroti dari pelayanan publik adalah pertama, mengenai ketebukaan informasi yang jelas seperti dalam bidang keuangan, belum tersedianya informasi secara jelas mengenai kebijakan relaksasi kredit kepada masyarakat. Kedua, belum adanya layanan secara jelas terkait prosedur dan mekanisme permohonan restrukturisasi 
kredit bagi sejumlah masyarakat yang telah memenuhi kriteria. Kemudian terkait layanan Kesehatan juga terdapat aduan bahwa kurangnya informasi tentang alur pelayanan kesehatan bagi masyarakat dengan gejala mirip Covid19 , termasuk informasi tentang tempat isolasi.

Kemudian diperkuat pula dengan Teori Kesejahteraan Negara oleh Muchsan, ciri-ciri negara hukum kesejahteraan menurut Muchsan adalah negara memiliki tujuan dalam memberikan kesejahteraan untuk warganya secara adil dan menyeluruh. ${ }^{23}$ Kesejahtraan itu dapat dipenuhi melalui penyelenggaraan pelayanan publik yang maksimal kepada masyarakat. Tanpa pelayanan yang baik dan merata mustahil akan terwujud kesejahteraan pada kehidupan masyarakat. Jika mengacu pada teori tersebut, maka untuk mewujudkan negara Indonesia menjadi negara kesejahteraan, maka pemerintah harus melakukan pelayanan publik yang maksimal bagi masyarakat dengan memperhatikan asas-asas penyelenggaraan pemerintahan yang baik sebagaimana yang telah diatur dalam UU AUPB.

Selain itu, dapat mengukur efektivitas sebuah peraturan maka peneliti menggunakan pula Toeri Efektivitas Hukum oleh Soerjono Soekanto yang dimana beliau menyatakan bahwa terdapat 5 (lima) faktor dalam mengukur efektivitas sebuah hukum yaitu:

1) Faktor hukum: hukum yang dimaksud di sini adalah hukum positif yang buat secara tertulis. Sebuah hukum tertulis dapat berjalan dengan baik atau tidak, tergantung pada aturan hukum tersebut (subtansi peraturan tersebut). Secara subtansi hukum, Indonesia telag memiliki seperangkat hukum yang mengatur terkait pelayanan publik yang baik yaitu di Undang-Undang Nomor 25 Tahun 2009 Tentang Pleyanan Publik. Bahkan dalam menjalankan fungsi dan tugas pelayanan publik sudah diatur harus mengacu pada asas-asas pelayanan publik yang baik sebagaimana yang diatur dalam Undang-Undang Nomor 30 Tahun 2014 Tentang Administrasi Pemerintahan. Secara subtansi,

23 Elviandri, Khuzdaifah Dimyati,dan Absori, "Quo Vadis Negara Kesejahteraan: Meneguhkan Ideologi Welfare State Negara Hukum Kesejahteraan Indonesia", Jurnal MIMBAR HUKUM Volume 31, Nomor 2, Juni 2019, hlm 252. 
peraturan tersebut sudah sangat jelas mengatur tentang pelaksanaan pelayanan publik dan asas-asas pemerintahan yang baik juga sudah diatur dengan runtun dan jelas sehingga seharusnya dalam pelaksanaan pelayanan public dapat sesuai dengan asas-asas umum pemerintahan yang baik tersebut.

2) Faktor penegak hukum: penegak hukum yang dimaksud adalah aparat atau orang yang bertugas dalam menegakan hukum tersebut. Penegak hukum dapat dikatakan efektif jika dilihat dari berbagai sudut yaitu sampai sejauh mana penegak tersebut terikat oleh peraturan-peraturan yang ada, sampai sejauh mana penegak diperkenankan memberikan kebijaksanaan, teladan yang diberikan penegak tersebut kepada masyarakt, sampai sejauh mana sinkronisasi penugasan yang diberikan. Penegak dalam hal ini adalah petugas atau aparatur yang menjalankan pelayanan public tersebut. Jika dilihat dari data yang masuk pada posko pengaduan Ombudsman (Tabel 2), masih ditemukannya kasus dimana petugas memimnta imbalan pada msyarakat saat proses pendaftaran penerimaan bantuan bansos tersebut.

3) Faktor sarana atau fasilitas yang mendukung penegakan: fasilitas yang dimaksud adalah fasilitas yang digunakan atau yang berhubungan dalam hal menjadi alat dalam mencapai efektivitas sebuah hukum. Berdasarkan data pengaduan yang masuk dalam posko pengaduan Ombudsman (Tabel 2), terdapat pengaduan dalam bidang transportasi yaitu tidak adanya sarana transportasi yang disediakan ke daerah asal bagi WNI yang baru dipulangkan dari luar negeri.

4) Faktor masyarakat, yakni lingkungan dimana hukum tersebut berlaku dan diterapkan: terdapat beberapa faktor yang dipengaruhi oleh masyarakat dalam mencapai efektivitas sebuah hukum yaitu masyarakat tidak patuh pada peraturan walaupun peraturan tersebut baik, masyarakat tidak mematuhi peraturan walaupun peraturan tersebut baik dan penegak hukum nya sangat baik, masyarakat tidak mematuhi peraturan tersebut walaupun peraturan, penegak dan fasilitasnya sangat baik dan memadai. Berdasarkan data yang masuk pada posko pengaduan Ombudsman Republik Indonesia 
(Tabel 2), terdapat aduan terkait penerimaan bansos yang dimana masyarakat tidak menerima bantuan bansos dikarenakan tidak memiliki KTP/KK. Hal ini menunjukan bahwa masyarakat sendiri tidak tertib administrasi, padahal pemerintah telah memberikan dan atau menyediakan bantuan bansos. Namun pada akhirnya bansos tersebut tidak tersalurkan dengan baik dikarenakan masyarakat yang tidak tertib administrasi.

5) Faktor kebudayaan, yakni sebagai hasil karya, cipta dan rasa yang didasarkan pada karsa manusia di dalam pergaulan hidup. Berdasarkan data yang masuk ke posko pengaduan Imbudsman Republik Indonesia, terdapat aduan tentang keamanan yang dimana tidak maksimalnya penertiban krumunan orang yang berkumpul pada zona PSBB. Hal ini menunjukan bahwa masyarakat sulit untuk mengubah budaya yang dahulu tidak diterapkan PSBB menjadi PSBB. Hal ini bukanlah hal yang mudah karena harus mengubah budaya yang biasanya berkrumun tanpa menggnakan masker dan menjaga jarak menjadi budaya yang harus selalu memakai masker dan menjaga jarak dimana pun kita berada.

Berdasarkan teori efektivitas hukum tersebut, maka dapat diketahui bahwa 5 (lima) faktor tersebut belum terpenuhi dalam pelaksanaan pelayanan publik di era pandemi Covid-19.

\section{Penutup}

Negara Indonesia adalah negara yang memiliki tujuan untuk mensejahterakan masyarakatnya. Dalam hal mensejahterakan masyarakat, maka penyelenggaraan pelayanan publik yang baik merupakan salah satu jalan dalam mewujudkan negara kesejahteraan. Pada era pandemi COVID-19 ini menimbulkan banyak sekali kebutuhan masyarakat yang perlu dipenuhi dan dilayani. Namun, hal yang ditemukan justru terdapat tren pengaduan pelayanan publik yang semakin meningkat di era pandemi COVID-19 ini yaitu dalam bidang bantuan sosial, kesehatan, keuangan, transportasi dan keamanan. Berdasarkan hasil penelitian, ditemukan bahwa penyelenggaraan pelayanan publik di era pandemi COVID-19 ini belum efektif dilaksanakan jika diukur dari standar pelayanan publik 
sebagaimana diatur dalam Pasal 13 Peraturan Pemerintah Republik Indonesia Nomor 96 Tahun 2012 Tentang Pelaksanaan Undang-Undang Nomor 25 Tahun 2009 Tentang Pelayanan Publik dan belum sesuai dengan asas-asas penyelenggaraan publik yang baik.

Oleh sebab itu, terdapat beberapa rekomendasi yaitu pertama, pemerintah seharusnya dapat menyiapkan orang yang khusus dalam menangani, menanggapi, dan menindaklanjuti segala aduan dan keluahan dari masyarakat terkait pelayanan publik yang terjadi selama pandemic COVID-19 ini agar khusus masalah pelayanan public terkait COVID-19 ditangani oleh satu pintu yang sama sesuai dengan asas keterpaduan (terpadu pada satu pintu). Kedua, perbaikan data yang akurat. Pendataan di pemerintahan harus mampu menyajikan data yang akurat agar bantuan sosial yang diberikan tepat pada sasaran. Ketiga, transparansi informasi. Pemerintah wajib menyiapkan informasi yang memadai dan terbuka untuk masyarakat. Keempat, perlu dibuatnya inovasi disemua sektor pelayanan publik yang ada, sebagai contoh sebenarnya sudah dilakukan pada sektor perizinan sebagaimana diatur dalam Pemerintah (PP) Nomor 24 Tahun 2018 tentang Pelayanan Perizinan Berusaha Terintegrasi secara Elektronik, bahwa pelayanan perizinan usaha harus dilakukan melalui online single submission (OSS). Namun, belum semua sektor diterapkan adanya layanan secara online. Kelima, perlu adanya partisipasi masyarakat secara aktif. Dalam hal ini, perlu disadari bahwa penyelenggaraan pelayanan publik memang merupakan tanggung jawab pemerintah namun penyelenggaraan pelayanan publik ini dalam terlaksana dengan efektif jika mendapat partisipasi/dukungan pula dari masyarakat. Hal ini selaras dengan salah satu asas dalam pelayanan publik yaitu asas partisipatif yang menyatakan bahwa perlu adanya partisipasi dari masyarakat dalam menyukseskan pelayanan publik. 


\section{Daftar Pustaka}

\section{Buku:}

Muchsan, Beberapa Catatan Tentang Hukum Administrasi Negara Dan Peradilan Administrasi Negara Di Indonesia. Liberty. Yogyakarta, 1981.

S.F Marbun, Dimensi-Dimensi Pemikiran Hukum Administrasi Negara, Cetakan Pertama, UII Press, Yogyakarta, 2001.

Utrecht, Pengantar Hukum Administrasi Negara Indonesia, Cetakan Keempat, Pustaka Tinta Mas, Surabaya, 1994.

\section{Jurnal:}

Ali Abdul Wakhid, Reformasi Pelayanan Publik di Indonesia, Jurnal TAPIs, No. 14 Vol. 01, Januari-Juni 2017.

Arfan Faiz Muhlizi, Reformulasi Diskresi Dalam Penataan Hukum Administrasi, Jurnal Rechts Vinding, Vol. 1 No. 1, Januari-April 2012.

Elviandri, Khuzdaifah Dimyati, dan Absori, Quo Vadis Negara Kesejahteraan: Meneguhkan Ideologi Welfare State Negara Hukum Kesejahteraan Indonesia, Jurnal Mimbar Hukum Vol. 31, No. 2, Juni 2019.

Eny Kusdarini, Asas-asas Umum Pemerintahan yang Baik pada Produk Hukum Perizinan Investasi Pemerintah Daerah, Jurnal JH Ius Quia Iustum, Volume 24 Issue 4, Oktober 2017.

Eny Kusdarini, Sunarso, dan Setiati Widihastuti, Pengembangan Asas-Asas Umum Pemerintahan yang Baik Melalui Local Wisdom Keraton Yogyakarta, artikel dalam Jurnal Penelitian Humaniora Vol. 21 No. 1 April 2016.

Jeffry Alexander Ch. Likadja, Memaknai "Hukum Negara (Law Through State)" dalam Bingkai "Negara Hukum (Rechtstaat)", Jurnal Hasanuddin Law Review Vol. 1 No. 1, April (2015).

M. Hamdani Pratama, Strategi Meningkatkan Kualitas Pelayanan Publik (Studi Deskriptif tentang Strategi UPTD Pengujian Kendaraan Bermotor Tandes Kota Surabaya dalam Meningkatkan Kualitas Pelayanan Pengujian Kendaraan Bermotor), Junral Kebijakan dan Manajemen Publik, Vol. 3, No. 3, September-Desember 2015.

Nur Rohim Yunus, Aktualisasi Welfare State Terhadap Kehidupan Bernegara Dalam Dimensi Keislaman dan Keindonesiaan, Jurnal Ilmu Syariah, Vol. 3 No. 2, 2015.

Sanggup Leonard Agustian, Asas-Asas Umum Pemerintahan Yang Baik Sebagai Batu Uji Bagi Hakim Dalam Memutus Sengketa Peradilan Administrasi Negara, Jurnal Hukum Magnum Opus, Vol. 2 No. 2, Agustus 2019.

Solechan, Asas-Asas Umum Pemerintahan yang Baik dalam Pelayanan Publik, Jurnal Adminitrative Law \& Governance, Volume 2 Nomor 3, Agustus 2019.

Tubagus Muhammad Nasarudin, Asas Dan Norma Hukum Administrasi Negara Dalam Pembuatan Instrumen Pemerintahan, Jurnal Hukum Novelty, Vol.7 No.2 Agustus 2016.

Veronika Erlin, Implementasi Prinsip Pelayanan Publik Di Kelurahan Tasikmadu Berdasarkan Peraturan Pemerintah No 96 Tahun 2012 Tentang Pelayanan Publik, Jurnal Ilmu Sosial dan Ilmu Politik, Volume 5, Nomor 1, 2016. 
Yuniar Kurniawaty, Penggunaan Diskresi Dalam Pembentukan Produk Hukum (The Use Of Discretion In The Formation Of A Legal Product), Jurnal Legislasi Indonesia, Vol. 13 No. 01 - Maret 2016.

\section{Situs Daring:}

Ombudsman Republik Indonesia, Dampak Pandemi Covid-19 Bagi Penyelenggaraan

Pelayanan Publik https://ombudsman.go.id/artikel/r/artikel--dampakpandemi-covid-19-bagi-penyelenggaraan-pelayanan-publik, diakses 10 Juni 2020.

Ombudsman Republik Indonesia, Mengawasi Pelayanan Publik Di Masa Pandemi Covid-19 ttps://ombudsman.go.id/artikel/r/artikel--mengawasipelayanan-publik-di-masa-pandemi-covid-19, diakses 24 September 2020.

Mahendra Bungalan, Suara Merdeka, Masyarakat Keluhkan Pelayanan Publik di
Masa
Pandemi,
Bisa
LAPOR!

https://www.suaramerdeka.com/news/nasional/233324-masyarakat-

keluhkan-pelayanan-publik-di-masa-pandemi-bisa-lapor, diakses 25

September 2020.

Kompas, Ombudsman Kantongi 387 Pengaduan Terkait Penurunan Kualitas

Layanan Publik di Pandemi

https://nasional.kompas.com/read/2020/05/14/10035381/ombudsman-

kantongi-387-pengaduan-terkait-penurunan-kualitas-layanan-

publik?page=all, diakses 25 September 2020.

Ombudsman, Selama Pandemi Covid-19, Ombudsman Terima 1.346 Pengaduan

Soal Bansos https://ombudsman.go.id/news/r/selama-pandemi-covid-19ombudsman-terima-1346-pengaduan-soal-bansos, diakses 19 April 2021.

Kompas, Ombudsman Kantongi 387 Pengaduan Terkait Penurunan Kualitas

Layanan Publik di Tengah Pandemi (https://nasional.kompas.com/read/2020/05/14/10035381/ombudsman -kantongi-387-pengaduan-terkait-penurunan-kualitas-layananpublik?page=all), diakses 19 April 2021.

\section{Perundang-undangan:}

Undang-Undang Nomor 25 Tahun 2009 Tentang Pelayanan Publik Undang-Undang Nomor 30 Tahun 2014 Tentang Administrasi Pemerintahan Peraturan Pemerintah Republik Indonesia Nomor 96 Tahun 2012 Tentang Pelaksanaan Undang-Undang Nomor 25 Tahun 2009 Tentang Pelayanan Publik

Pemerintah (PP) Nomor 24 Tahun 2018 tentang Pelayanan Perizinan Berusaha Terintegrasi secara Elektronik 